food industry, especially fast-food outlets. She is correct to identify them as one of many aetiological agents, but she fails to take account of modern family life in which parents are working and have too little time for family pastimes. She discusses physical activity, or rather the lack of it, but the book touches only briefly on the "couch potato society".

The Hungry Gene is aimed at a lay readership and is an interesting read. The author has certainly worked hard to uncover scientific theories, and supports her arguments with an extensive bibliography that includes several scientific publications. She brings the book alive with her investigative-journalistic (docu-journal) style. However, much of the more controversial evidence comes from conversations with scientists and their colleagues, or from newspaper articles, rather than evidence-based scientific reports. Some may dispute the glamorization of the science of a modern-day societal problem with the implication, by its title, that its origin is entirely genetic. Nevertheless, the book does largely represent current scientific thinking.

The detective story that identifies the victim reveals many culprits: the author concludes that "science has taught us that the obesity pandemic is less a matter of individual differences than of societal pressures, and of the power of the institutions that impose them". Perhaps a fairer title for the book, as suggested by Dr Johnson, would be "The Hungry Society" - but that might not sell. Peter Kopelman is at Barts and the London, Queen Mary's School of Medicine and Dentistry, University of London, Turner Street,

London E1 2AD, UK.

\section{Clinical science not to be sneezed at}

\section{Cold Wars: The Fight Against the Common Cold}

by David Tyrrell and Michael Fielder Oxford University Press: 2002. 268 pp. $\mathfrak{E} 17.99, \$ 24.95$

\section{Nigel Dimmock}

Now rapidly fading from memory, the UK Medical Research Council's Common Cold Unit (CCU) was a uniquely British venture, where volunteer members of the public stayed for two weeks for virtually no payment as human guinea-pigs. Probably in no other country could such altruism be found. The volunteers (and staff) lived on site in some comfort in prefabricated, singlestorey, converted hospital wards on a windy hillside outside Salisbury in rural southwest England. The volunteers, who often came again and again, were incorporated into double-blind, placebo-controlled clinical

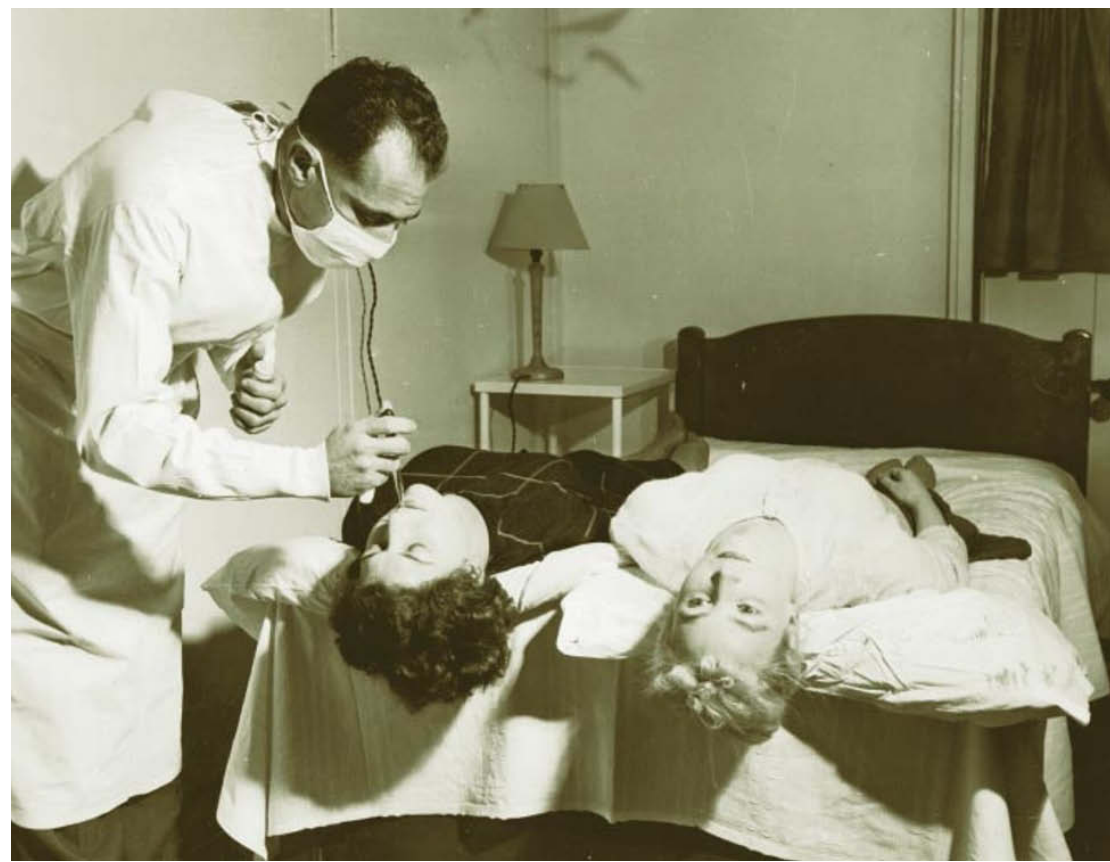

Chilling out: volunteers at the Common Cold Unit were infected with cold virus in a bid to find a cure.

trials, and therein lay the uniqueness of the CCU: real people were placed in a totally objective experimental situation.

In the late 1940s and 1950s, volunteers were infected predominantly with viruses (extracts of nasal secretions from people with colds) that could not be grown in cultured cells. Later there were other investigations, including trials of antivirals (it was home to the first clinical evaluation of $\alpha$-interferon), the evaluation of psychological parameters such as susceptibility to infection, and the effect of colds on hand-to-eye skills. Today's scientists will look enviously at the timescale over which funding continued despite there being no substantial progress; the funding was largely due to the upbeat personality and influence with the Medical Research Council of the CCU's director at the time, Christopher Andrewes.

Cold Wars is the story of the CCU, as told by its director for its final 30 years, David Tyrrell, and co-author Michael Fielder. The authors give a thorough account of common colds from prehistory onwards. We are told of the establishment of Harvard Hospital in 1941 as a potential Second World War front-line facility by Harvard Medical School and the American Red Cross, and of its conversion after the war by Andrewes to the CCU.

These were the early days of cell culture, which had only recently been made practicable by the industrial-scale production of antibiotics. The problem of growing cold viruses was cracked in the late 1950 s by a combination of logic (human viruses are most likely to grow in human cells, and at $33^{\circ} \mathrm{C}$, the temperature of the nasal cavities) and serendipity (a faulty batch of medium).

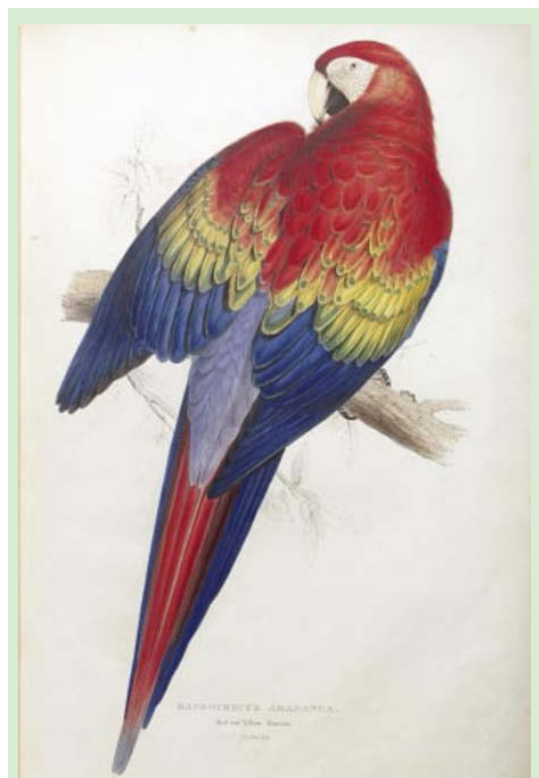

\section{The red parrot sketch}

Edward Lear is best known for his nonsense verse, but he was also an accomplished artist. At the age of 19 he was keen to establish himself as a painter of natural history and published Illustrations of the Family of Psittacidae, or Parrots, a collection of 42 hand-coloured lithographic plates, including one of a red and yellow macaw (above). These were greeted with great enthusiasm and compared to the work of John James Audubon. This rare collection of ornithological plates has now been published in PDF format by Octavo (www.octavo.com). 
It did not take long to show that cold viruses are physically related to poliovirus, but differ in the sensitivity of their infectivity to low $\mathrm{pH}$. This made sense because cold viruses cause respiratory infections and do not have to withstand gastric acidity. The characterization of the viral genome - an infectious, single strand of RNA - was published in Nature (204, 792-794; 1966).

I was recruited to the CCU by Andrewes in 1961, to characterize the fundamental nature of cold (now rhino-) viruses. Being at the CCU was a steep learning curve for a young scientist - I was expected to master viral biochemistry and biophysics, and become familiar with clinical virology. In addition, the international reputation of the CCU ensured a stream of eminent visitors to rural England from countries around the world, from the United States to the Soviet Union. Each member of staff, even the newest recruit, was expected to tell these luminaries their latest findings. The world's press also paid an annual visit. Meanwhile Andrewes, who had retired and come to live nearby, often dropped in, timing his visits for tea and cucumber sandwiches, which were the norm in those days! Andrewes was a consummate raconteur who demanded an audience, but not reciprocity.

Does the book work? Yes, because Tyrrell and Fielder write sound but instantly understandable science. However, the core of the book is made up of Tyrrell's personal insights during the time that he presided over the $\mathrm{CCU}$ as the clinician-scientist. $\mathrm{He}$ was renowned for his hard work, boundless enthusiasm and encouragement to all those around him. Everyone who worked at the CCU could add his or her own reminiscences of what was a very interesting place at which to work and, for most of us, to live. Personally I owe Tyrrell an enormous debt for his sympathetic help with my PhD studies.

This is a history of science over the past 50 or so years - a science that is almost unrecognizable now - and an account of how a great many scientists, clinicians, lay staff and volunteers made a huge contribution to the understanding of the common cold, but sadly formulated no cure. But what of the demise of the CCU? We are told simply that it outlived its usefulness and was closed in 1990. It would have been good to know why. Was this just misguided short-termism, and if it had it become too expensive, why was no public-private partnership (with the pharmaceutical industry?) put in place to save such a valuable clinicaltrial facility? The site is now a housing development; at its entrance on the Blandford road, a small plaque notes that here the CCU was once located.

Nigel Dimmodk is in the Department of Biological

Sciences, University of Warwick,

Coventry CV4 7AL, UK,

\section{Science in culture}

\section{Time will tell}

DNA is used as a symbol of hopes and fears in the genetic revolution.

MartinKemp

A human figure, naked and male (as far as we can tell in the absence of genitals), turns his face and the palms of his hands to the heavens, like one of the ascending elect in Michelangelo'spainting Last Judgement. Standing atop thekind of classical cohumn reserved for military heroes, he adopts a space-filling pose reminiscent of Leonardo da Vinci's famous man tracing the figures of a square and circle with outstretched limbs. He is fringed by a halo of light that obeys none of the laws of terrestrial optics.

This was the imagethat appeared on the cover of Time magazine on 17 Jamuary 1994. It now features in the exhibition "Representations of the Double Helix", curated by Sor aya de Chadarevian and Harmke Kamminga at the Whipple Museum of the History of Science in Cambridge, UK. The cover draws attention to an article inside on "The Genetic Revolution" by Philip ElmerDewitt, subtitled "New technology enables us to improve on nature. How far should we go? ${ }^{\circ}$ Francis Collins of the US National Institutes of Health (now director of the National Human

Genome Research Institute) was cited as comparing the challenge with splitting the atom or going to the Moon.

The centrality of DNA to the genetic quest is signalled by its spiralling presence in the figure's thorax and abdomen, reminiscent of a giant structural spine. It is assumed to be an instantly identifiable icon for Time's international readership, recognized even when, as here, the helices twist in the wrong direction. It would be interesting to take a census of how often this reversal has occurred in the 50-year iconography of the great molecule.

We read on the cover that ${ }^{\circ} \mathrm{New}$ breakthroughs can cure diseases and save lives" - a promise that has been more hyped than realized - but the positive connotations are anxiously tempered by the question "how much should nature beengineered?" The eerie, night-time atmosphere of the cover evokes a sciencefiction realm in which excitement and fear are mingled, Frankenstein-like.

Such is the fame ofDNA that it has featured on at least three other Time covers over a 32-year span: 19 March 1971, 13 September 1999 and 17 February 2003 (in the US edition, but 3 March 2003 in Europe). The most recent of these shows a modern Adam and Eve standing wreathed in golden helices that branch aloft into a fruiting tree of life (or of sinful knowled ge?). The lead artide on this occasion, written by Nancy Gibbs, deals with ${ }^{\alpha}$ The Secret of Life", and aims to show how "Cracking the DNA code has changed how we live, heal, eat and imagine the future".

the

Wetake the familiarity of DNA so much for granted that it is difficult to see its high profile as exceptional. How many abbreviated chemical namesmean anything in the broader public domain? $\mathrm{H}_{2} \mathrm{O}$ and $\mathrm{O}_{2}$ are familiar enough, and $\mathrm{CO}_{2}$ has gained prominence in relation to global warming. All three have oxygen in common, which seemed to hold the promise of the secret of lifein the late eighteenth and early nineteenth centuries. Like AIDS, HIV and, perhaps, BSE, its actornymic identity has achieved independence from any widespread awareness of its fill name or chemistry.

The triumphant story of DNA is marked by signposts that become selectively significantwhen we retrospectively know where history was taking us. As Robert Olby showed in his recent article in Nature (421,402-405; 2003), the great majority of papers on DNA up to 1960 made no mention of James Watson and Francis Crick's structure (Nature 171, 737-738; 1953) - it remained something of a 'sleeper.' Thelaconic visual and verbal presentation of their paper, which was a factor in its slow rise to fame, seems astonishing in retrospect, but we would do well to remember Watson and Cridk's acknowledgement that "The previously published $X$-ray data ... are insufficient for a rigorous test of our structure. So faras well can tell, it is roughly compatible with the experimentaldata, but it mustbe regarded as unproved until ithas beenchedked against more exact results." Martin Kemp is in the Department of the History of Art, University of Oxford, Oxfond OXI 2BE, UK.

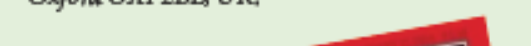

